\title{
NUEVOS DATOS SOBRE LA CONSTRUCCIÓN DEL PUENTE DE ALMARAZ (CÁCERES)*
}

\author{
POR \\ Ana Castro Santamaría \\ Universidad de Salamanca
}

El puente de Almaraz (Cáceres) es uno de los más interesantes del siglo XVI español y, sin embargo, poco se conocía de su historia constructiva. A través de varios pleitos localizados en los Archivos de Simancas y de la Chancillería de Valladolid se ha podido recomponer su biografía, desde finales del siglo XV hasta ser definitivamente retomado en los años 30 del siglo XVI, por iniciativa de la Mesta y bajo la maestría de Juan de Álava y Martín de la Ordieta como aparejador. El puente entonces iba a tener tres arcos y su trazado no era recto. En 1539 se hizo con los destajos Diego de Vergara y se producen cambios fundamentales, sobre todo la reducción del número de arcos a dos. No obstante, en 1542 en que cesan las informaciones, no se había logrado siquiera acabar el primero de los dos arcos, fundamentalmente por problemas económicos derivados de la corrupción que afectó a la gestión a todos los niveles.

Palabras clave: Puentes, Almaraz (Cáceres), Extremadura, siglo XVI, Concejo de la Mesta, Juan de Álava, Martín de la Ordieta, Diego de Vergara.

The Almaraz bridge (Cáceres) is one of the most interesting of the XVIth century in Spain. Nevertheless, its constructive history was scarcely known. Through several lawsuits located in the Archives of Simancas and the Chancillería of Valladolid, it has been possible to reconstruct its biography, from the end of the XVth century until the definitive campaign retaken in the fourth decade of the XVIth century, by initiative of the Concejo de la Mesta and under the direction of Juan de Álava and his technical assintant Martín de la Ordieta. At first, the bridge was thought to have three arches and its layout was not straight. In 1539, Diego de Vergara took control of the piecework and fundamental changes took place, mainly the reduction of the number of arches to two. However, in 1542 when the informations ended, they had not managed to finish the first of the two arches, fundamentally because of economic problems derived from the corruption that affected the management at all levels.

Key words: Bridge, Almaraz (Cáceres), Extremadura, XVth century, Concejo de la Mesta, Juan de Álava, Martín de la Ordieta, Diego de Vergara.

\footnotetext{
* Este trabajo ha sido financiado y realizado como parte del proyecto de investigación "Patrimonio tardogótico en Castilla: los arquitectos (1440-1575)", Plan Nacional I+D+I, Ministerio de Educación y Ciencia (ref. HUM 2004-02530).
} 
“...de solos dos arcos..., la cual en grandeza, traza, fortaleza y hermosura puede competir con las mas famosas obras romanas, y causa admiración á todos los que la ven..." Fray Alonso Fernández, $1627^{1}$

El puente de Almaraz en la provincia de Cáceres es sin duda uno de los más bellos de España, pero su historia aún no es suficientemente conocida. Hasta ahora, teníamos noticia parcial del desarrollo de las obras entre 1533 y 1537 y de la intervención de Diego de Vergara en los destajos del puente entre 1540 y $1542^{2}$. Estas páginas pretenden ofrecer nuevos datos sobre su proceso constructivo procedentes fundamentalmente de la documentación generada por varios pleitos custodiados en el Archivo de Simancas y en la Real Chancillería de Valladolid.

El puente recibe el nombre de Almaraz o de Albalá, el primero por encontrarse próximo a esta villa cacereña y el segundo derivado del árabe "al-Belat" con el que se denominaban estas tierras, por el nombre del castillo que las encabezaba. Levantado sobre el río Tajo, formaba parte del camino principal de Toledo a Andalucía y era paso obligado en la ruta Madrid-Lisboa ${ }^{3}$.

Fue construido en sillería de granito por fuera, con ripio por dentro; lleva rasante horizontal y dos ojos de grandes proporciones, que ostentaron durante mucho tiempo el mérito de tener la bóveda de mayor luz de España: 38 metros uno de los arcos y 32 el otro, siendo la longitud total 127 metros $^{4}$.

El puente sufrió una destrucción parcial en la Guerra de la Independencia, pero podemos imaginar su aspecto original gracias a un grabado de Sánchez Taramas de 1769, donde apreciamos el uso de la triple rosca de dovelas, lo que permitió aligerar la resistencia de la cimbra, puesto que la primera rosca soporta el peso de las otras dos ${ }^{5}$.

El arco de mayor luz es de medio punto, está situado en dirección a Almaraz (al Norte) y no es el original, pues fue restaurado en 1845 por Manuel Ibáñez, un lego exclaustrado de la Compañía de Jesús 6 .

\footnotetext{
${ }^{1}$ Llaguno y Amirola, E.; Noticias de los Arquitectos y Arquitectura de España desde su Restauración. Ilustradas y acrecentadas con notas, adiciones y documentos por D. Juan Agustín Ceán-Bermúdez, Madrid, 1829, pp. 168-169, citando a fray Alonso Fernández en su Historia de Plasencia, fol. 15.

2 Condesa de QuinTANILla; "Datos sobre la construcción del puente de Almaraz", Revista de Estudios Extremeños, Badajoz, XIV, 1958, pp. 244-246. LLORDÉN, A.; Arquitectos y canteros malagueños: ensayo histórico documental (siglos XVI-XIX), Ávila, 1962, p. 17.

3 Hernández García, V.; Almaraz, una villa con historia, Madrid, 1980, p. 195. Heredia CAmpos, M.C.; "Puente de Almaraz. De cuño imperial”, Revista del Ministerio de Fomento, Madrid, no 53, 2004, p. 23.

${ }^{4} \mathrm{La}$ anchura es de 6,80 sin los pretiles. Ponz y Ceán ofrecen estas medidas: el arco de medio punto tiene 150,5 pies de ancho y 69 de alto; el apuntado 119 y 66 respectivamente, 580 pies de longitud total, 25 de ancho y 134 de altura hasta los pretiles. En 1539, los canteros Juan Correa y Martín de la Ordieta midieron la distancia entre sus pilares extremos y central, resultando 147 y 112 pies, correspondiendo la primera medida al arco grande. Archivo General de Simancas (en adelante, A.G.S.), Consejo Real 547, s.f. Llaguno y Amirola, op. cit., vol. II, p. 57. Mélida, J.R.; Catálogo Monumental de España. Provincia de Cáceres (1914-1916), Madrid, 1924, p. 291. GonZÁLEZ TASCón, I.; Felipe II, los ingenios y las máquinas. Ingeniería y obras públicas en la época de Felipe II, Madrid, 1998, p. 124. ARENAS, J.J.; Caminos en el aire: los puentes, Madrid, 2002, vol. 1, p. 318.

5 Muller, J.; Tratado de fortificación, ó Arte de construir los edificios militares, y civiles escrito en ingles, por Juan Muller; traducido en castellano, dividido en dos tomos, y aumentado con notas, adiciones, y 22 láminas finas sobres las 26, que ilustran al original, por Miguel Sánchez Taramas, Barcelona, 1769, tomo segundo, pp. 72-73. ARENAS, op. cit., vol. 1, pp. 322-326. GoNZÁLEZ TASCón, op. cit., p. 124.

${ }^{6}$ Más detalles de la destrucción y reconstrucción decimonónicas en HERNÁNDEZ GARCía, op. cit., pp. 208-220.
} 
El otro arco es apuntado, con la particularidad de que mantiene la curvatura de la bóveda de cañón del vano mayor. Esto aporta dos ventajas, como señala Arenas: el arco apuntado se puede resolver con los mismos sillares que el arco de medio punto y la cimbra será en buena parte reutilizable 7 .

Se asienta sobre tres pilares, dos en los extremos y uno en el centro del cauce, aprovechando un saliente rocoso, actualmente cubierto por las aguas (debido al embalse de Valdecañas) pero visible en el grabado de Sánchez Taramas. Este pilar central presenta tajamar y espolón triangulares, de los que parten prolongaciones semicilíndricas hasta formar apartaderos. La presencia de estos pesados tambores es un rasgo de cierto arcaismo que caracteriza a los puentes españoles de la segunda mitad del siglo $\mathrm{XVI}^{8}$.

\section{Primeras noticias del puente de Almaraz}

La más antigua referencia del puente de Almaraz que hemos recogido se remonta a finales del siglo XV y atribuye la iniciativa de la construcción a don Francisco de Monroy, señor de Belvís. En 1497 la ciudad de Plasencia (a cuya jurisdicción pertenecía Albalá) consiguió evitar que continuara la obra, pues la ciudad obtenía las mejores rentas del transporte de ganado en barcas ${ }^{9}$.

La importancia de Albalat radicaba, por tanto, en el paso de ganados, pues formaba parte de la cañada leonesa occidental. Por ello, sería la Mesta la más interesada en su construcción. Una cédula de la reina doña Juana del 27 agosto de 1514 nos informa que el concejo de la Mesta había solicitado su construcción para sustituir las barcas, pues "al pasar... se ahogan e pereçen mucha parte del dicho ganado y asimismo mucha gente". El impedimento, de nuevo, vino de parte del concejo de Plasencia, pues obtenía cuantiosos beneficios de las barcas ${ }^{10}$.

\section{La construcción entre 1530 y 1536: Juan de Álava y Martín de la Ordieta}

Hasta 1530 o 1531 no se vencieron las reticencias del concejo de Plasencia. Por estas fechas, la obra fue definitivamente retomada por Juan de Álava, según declara en 1539 su aparejador, el cantero Martín de la Ordieta. Parece confirmarse así la atribución -intuitiva, más que documentada- formulada por Llaguno a principios del siglo XIX ${ }^{11}$.

\footnotetext{
7 ARENAS, op. cit., vol. 1, p. 322. De hecho, también se utilizó en el desaparecido puente sobre el río Apurímac, en el Camino Real de Cuzco a Lima, en el virreinato de Perú, proyectado alrededor de 1619 por el ingeniero Bernardo Florines y el maestro de cantería Diego Guillén. Archivo General de Indias, Perú y Chile, 203. GonZÁLEZ Tascón, op. cit., p. 125.

8 GONZÁLEZ TASCÓN, op. cit., pp. 115-116 y 129.

9 A.G.S., Registro General del Sello (en adelante, R.G.S.), 5-12-1497. Las barcas de Almaraz se documentan desde el siglo XIV. HERNÁNDEZ GARCÍA, op. cit., p. 196.

${ }^{10}$ La cédula en A.G.S., R.G.S., 27-8-1514. En el Archivo Municipal de Plasencia se documenta el funcionamiento de las barcas hasta 1526 en el único libro de Actas que se conserva (Libro de Acuerdos del Ayuntamiento, 1522-1526). En 1540 todavía se habla del barquero, vid. infra. Sobre las competencias de la Mesta en la construcción de puentes, ver Molenat, J.P.;"Les communications en Nouvelle Castille au XVe siècle et au debut du XVIe siècle", en Les communications dans la Péninsule Ibérique au Moyen-Age, Paris, 1981, p. 158. Aramburu-Zabala Higuera, M. A.; La arquitectura de puentes en Castilla y León (1575-1650), Valladolid, 1992, p. 28. En la visita al puente del 6 de marzo de 1536 se habla de que la Mesta aportó 70.000 mrs. A.G.S., Consejo Real 547, s.f. Sobre el paso de la cañada, García Martín, P.; El Patrimonio Cultural de las Cañadas Reales, Valladolid, 1990, p. 34.

${ }^{11}$ Llaguno apuntaba el nombre de Juan de Álava a partir de la atribución de la obra a Fray Martín de Santiago por parte del historiador dominico fray Alonso Fernández. LlagunO y AMIROLA, op. cit., pp. 168-169. El 2 de marzo de 1539 Martín de la Ordieta declara que se había ocupado de la obra del puente desde sus inicios bajo la maestría de Juan de
} 
Álava era maestro mayor de la Catedral de Plasencia al menos desde 1517; en 1523 trabajó también para el concejo de esta ciudad, dando trazas para el nuevo ayuntamiento y para unos reparos del puente de Trujillo ${ }^{12}$.

Martín de la Ordieta (o de Lorrieta) fue aparejador de la obra desde el principio de esta nueva campaña. Era el responsable del discurrir diario de la obra, sujeto a las directrices del maestro, que efectuaba una visita anual. La comunicación entre ambos no siempre se traducía en sintonía, como demuestra la descalificación que hizo de él Juan de Álava con motivo del "esgonçe", del que hablaremos inmediatamente. Esta sería la primera obra documentada de Ordieta, vecino de la ciudad de Plasencia y "natural de la casaria de Ordieta", nacido alrededor de 1500. Noticias posteriores le relacionan con otros puentes: en 1532 trabaja en el puente romano de Alcántara y en 1538 en el de San Lázaro de Plasencia ${ }^{13}$.

Sobre las características de este primitivo puente, obtenemos algunos datos de las declaraciones de testigos. Por ejemplo, el trazado no era recto, sino que hacía un quiebro o "esgonçe", en la zona más cercana a Almaraz, junto al risco rocoso. El origen de este quiebro se remonta a las obras más tempranas, de finales del XV. Pudo haber sido enmendado por Álava, quien no debió considerarlo oportuno, pues a su entender mantenía íntegra su fortaleza. Además, el puente estaba planteado con tres ojos: un gran arco hacia la parte de Almaraz (hacia el risco, como dicen los documentos) y dos más pequeños a continuación, en vez del segundo gran ojo que ahora presenta ${ }^{14}$.

Los primeros trabajos comenzarían con la construcción de los pilares, con la ventaja de que se cimentarían en seco, aprovechando los salientes rocosos de las riberas y un peñasco en medio del cauce para el pilar central. Desde 1533 se trabajaba en destajos simultáneos, uno a cargo del aparejador Martín de la Ordieta y otro a cargo de Pedro de Ávila. Desde estas mismas fechas hay noticias relativas a la extracción de piedra, compra de sogas, clavazón y guindaletas, afilado de herramientas y pago a peones ${ }^{15}$.

Álava, hacía ocho o nueve años. A.G.S., Consejo Real 547, s.f., de donde procede la información de este apartado (salvo que se indique otra fuente). Según HEREDIA CAMPOS, art. cit., p. 23, las obras no comenzaron hasta 1533, por orden de Carlos I.

12 Castro Santamaría, A.; Juan de Álava, arquitecto del Renacimiento, Salamanca, 2002, pp. 491-493 y 496-497.

13 Sin embargo, en sus declaraciones de 1539, al ser preguntado si había asumido las obras de algún otro puente, contestó negativamente, aunque precisando que en una ocasión concursó y obtuvo el remate de la obra del puente de Alcántara para su suegro (Martín López). Según estas mismas declaraciones, el maestro Juan de Álava despreciaba sus opiniones por su falta de capacitación. A partir de 1539 está documentado en diversos edificios religiosos: Catedral de Plasencia, iglesia de Gata (1539-1543), sacristía de la parroquia de Almocóvar (1540); moriría en Indias. NAVAREÑo Mateos, A. y SÁnchez Lomba, F.M.; "Vizcaínos, trasmeranos y otros artistas norteños en la Extremadura del siglo XVI”, Norba-Arte, Cáceres, IX, 1989, p. 10. SÁNCHEZ LomBA, F.M.; "Observaciones sobre reformas en el puente romano de Alcántara”, Norba-Arte, Cáceres, V, 1984, p. 313. SÁnCHEZ LoMBA, F.M.; Iglesias caurienses del milquinientos, Cáceres, 1994, p. 101.

${ }^{14}$ Al ser preguntado Ordieta si sabía el por qué del esgonce, contestó que Álava lo encontró comenzado y no lo modificó. Opina que hubiera sido posible enderezar el puente simplemente subiendo los pilares de la otra parte del río. No obstante, cree que la obra será fuerte, firme y duradera, y por ello está dispuesto a dar fianzas; el único problema sería la fealdad del quiebro. La existencia de un pilar pequeño además del central principal -que determinaría la existencia de tres arcos- la conocemos a partir de la propuesta de Correa y Ordieta del 2 de marzo de 1539 de eliminar el pilar pequeño y dejar sólo dos arcos.

15 En la documentación constan diversos pagos a los destajeros: Martín de la Ordieta cobra 60.000 mrs. el 27 de septiembre de 1533 y otros tantos el 18 de octubre del mismo año. En 1536 recibe 12 reales por tres días que se ocupó en ir a la obra a ver la cal y otros materiales para que Pedro de Ávila comenzase su destajo, y para darle herramientas y otras cosas necesarias; más adelante recibió otros $30.000 \mathrm{mrs}$. como parte de pago de los destajos de los llamados "pilares viejos". Por su parte, Pedro de Ávila cobra 30.000 mrs. el 17 de octubre de 1533 del destajo de las hiladas del puente y el 30 del mismo mes 1.500 mrs. de los andamios de los pilares. En 1536 recibe en tres ocasiones un total de $75.000 \mathrm{mrs}$. 
Sin embargo, desde mediados de 1534 y al menos hasta marzo de 1536, cesan los trabajos. En este tiempo, los aparejos se deterioraron y algunos de los materiales serían vendidos. Ello provocaría la visita de la obra por parte de un miembro del Consejo Real, Pedro Girón, pues no podemos olvidar que el Consejo Real o Consejo de Castilla era el organismo que autorizaba cualquier obra pública ${ }^{16}$. El 6 de marzo de 1536, acompañado por Hernando de Barrientos, corregidor, y con los regidores Francisco de Collazos y García de Carvajal, visitaron el puente de Almaraz y revisaron sus cuentas. Tomaron algunas resoluciones respecto a la gestión económica, que analizaremos más adelante, y además determinaron que la obra debía ser visitada por el maestro principal -Juan de Álava, probablemente- y otros maestros para decidir respecto a los destajos.

\section{Las visitas de 1537, 1538 y 1539}

A partir de 1536 las visitas por parte de algún miembro del Consejo Real -o incluso del propio presidente del Concejo de la Mesta- se producen anualmente. El 28 de febrero de 1537 Pedro Girón volvió a reconocer la obra. Obtuvo información (sobre el ritmo de las obras, el material empleado y las previsiones de los costes) del aparejador Martín de la Ordieta, Juan de la Renta, cantero asentador, y Pedro de Ávila, cantero labrante. En un mes (de finales de enero a finales de febrero de 1537) Pedro de Ávila había colocado diez hiladas de piedra en el pilar del risco, pero aún quedaban treinta hiladas hasta el arranque del arco. Se emplearon sillares para el exterior y mampostería, pizarra, cal y arena en el interior; se cuestiona si continuar así o reducir el uso de la sillería a los arcos y esquinas de los tajamares, empleando en el resto mampostería, pizarra y cal. Ordieta y Ávila lo desestiman por el contraste y fealdad que causaría la zona inferior de sillería y la superior de mampuesto, que acabaría con el aspecto suntuoso de la obra. Ordieta llevaba quince días trabajando en los dos pilares viejos o intermedios que entonces llevaba el puente, guarneciendo las delanteras de algunas piedras que habían perdido y que debían alcanzar la altura de los extremos; al pilar grande central le faltaban dos hiladas y al otro unas quince. En cambio, en el pilar del extremo opuesto (hacia la venta, dicen los documentos), nada se había hecho. Cuando se les pregunta cúanto costaría finalizar los dos pilares grandes y el arco con su cimbra, calculan la cifra de 12.000 o incluso 15.000 ducados. Pedro de Ávila opina que, dada la amplia luz del arco, serían necesarias "dovelas de a tres pies e anillos, todo ello que sean doblados porque el foyo del dicho es grande" 17.

Por tanto, se seguía trabajando en los pilares, especialmente en el grande que estaba hacia Almaraz y la intención era construir únicamente uno de los arcos del puente, el más próximo a Almaraz, y así lo determina el 1 de marzo de 1537 Pedro Girón, quien manda proseguir "la dicha obra de los pilares grandes e arco principal", reservando una pequeña cantidad de dinero (60.000 mrs.) "que se an gastado en los pilares viejos". Este sistema constructivo "a la romana" era habitual en el siglo XVI: las bóvedas se hacían de una en una, aprovechando en lo posible la misma cimbra ${ }^{18}$.

del destajo de las hiladas del pilar del risco. Los pagos por utillaje y materiales diversos continúan en años sucesivos: así, en 1536 se pagaron por "robenales" y clavijas para los andamios, una maroma, dos guindaletas; en 1539 se alude a un "tiro" que hizo Ordieta en el pilar del risco. A.G.S., Consejo Real 547, s.f. Ver también QuinTanILla, art. cit., pp. $242-244,246$ y 247.

16 Aramburu-Zabala, op. cit., pp. 26 y 28. En la provisión real del 3 de febrero de 1536 ya se habla de una visita a la obra que habían cursado el licenciado Girón y el doctor Montonya, miembros del Consejo.

17 Posteriormente, en 1539, las dovelas elegidas para el arco serán las de seis pies. A.G.S., Consejo Real 547, s.f., de donde procede la información de estas visitas, en las que también se informa de la existencia de una casa en la que se guardaban los pertrechos e incluso se alojaban los trabajadores de la obra. Ver también QuinTANILLA, art. cit., pp. 248-250.

18 GonZÁlez TASCÓN, op. cit., p. 122. 
Tres cuestiones quedan pendientes de decidir: la colocación de la cimbra del arco principal (se podría colocar inmediatamente sobre los pilares o prolongando estos en altura); el material que debía utilizarse (hasta el momento era sillería por fuera con relleno de mampostería y pizarra, pero se podría hacer de mampostería con las esquinas de sillería); por último, habrá de decidirse si continuar las obras a destajo o a jornal.

El 2 de marzo de 1538 el incumplimiento de lo dispuesto por Pedro Girón hace que el presidente del Concejo de la Mesta determine una nueva visita de la obra, para informarse de la administración del dinero, pues se corría el peligro de que si la obra cesaba, se perdería y acabarían vendiendo los materiales "como otras vezes lo han hecho". En el contexto de esta nueva visita, comparece una vez más Martín de la Ordieta, a quien se nombra como "aparejador e maestro" del puente, pues Juan de Álava ya había muerto ${ }^{19}$.

El diagnóstico de la situación es claro: "paresçe aver negligencia en la dicha obra por falta de no andar en ella los ofiçiales necesarios". La solución consiste no sólo en dividir la obra en dos destajos, como hasta entonces se había hecho para acortar tiempo, sino en colocar un número suficiente de trabajadores en cada uno: "que en el pilar del risco continuamente anden dos asentadores e diez peones e un aparejador y en el pilar principal anden dos asentadores y quinze peones e un aparejador, por manera que en cada uno de los dichos pilares tenga obra por sy, porque se pueda hazer con más brevedad" 20.

El 1 de marzo de 1539 se produce una nueva visita al puente, estando presente Martín de la Ordieta, juntamente con un representante del Consejo Real y del regimiento de Plasencia. El estado de la obra era el siguiente: los pilares que sostendrían el arco del Norte (hacia Almaraz) iban más avanzados (el del risco tenía 32 hiladas sobre los tajamares y el pilar grande 27 hiladas sobre los tajamares), mientras que los del Sur sólo se elevaban sobre la tierra 10 o 12 hiladas (tanto el "pillarejo pequeño" como el "estribo hazia la venta").

Se inicia un periodo de consultas a maestros canteros, entre los cuales estaban, además del aparejador Martín de la Ordieta, Juan Correa y Cristóbal Méndez. Este último era "maestro de cantería que haze la puente de Vadajoz"; el 25 de febrero de 1539 ya había sido llamado por el rey por medio de una carta, pero el 2 de marzo se señala que por estar "mal dispuesto no ovo podido venir... por manera que, sy caminara, recibiría mucho detrimento en su salud".

Correa, aparejador de las obras de la Catedral de Plasencia, ya había pedido licencia al cabildo para examinar el puente de Alvalá, a requerimiento del regidor de Plasencia, el 20 de diciembre de 1538. A esta visita probablemente se refiere en el interrogatorio del 2 de marzo de 1539, en el que nos ofrece datos muy interesantes de su currículum. Se dice maestro de cantería, vecino y natural de Plasencia, donde "tiene a su cargo la obra de la iglesia mayor", dato ya conocido. Lo desconocido hasta ahora eran sus relaciones profesionales con los condes de Oropesa y de Medellín: por encargo del primero (entonces Francisco Álvarez de Toledo, II Conde de Oropesa), declara hacer un monasterio franciscano en Oropesa, además de un patio en su palacio, mientras que su relación con el conde de Medellín parece que se limitó a una visita del puente de Medellín²1.

\footnotetext{
${ }^{19}$ Su declaración no precisa mucho: simplemente expone su impresión sobre la mala administración del dinero por parte del regimiento de la ciudad de Plasencia, eximiendo de responsabilidad a los trabajadores. Calcula que la obra necesitaría 30.000 ducados para ser acabada en perfección. Sorprendentemente, se habla por primera vez del arco del puente: se dice literalmente que el licenciado Álava se puso encima del arco del puente que está hecho hacia la villa de Almaraz.

${ }^{20}$ Por tanto, la organización es similar -por ejemplo- a la de El Escorial, donde la cuadrilla ideal se consideraba la compuesta por un maestro y veinte canteros. BARrio LoZA, J.A. y MOYA VALGAÑón, J.G.; "El modo vasco de producción arquitectónica en los siglos XVI-XVIII", Kobie, Bilbao, n 10, 1980, p. 312.

${ }^{21}$ En un interrogatorio que presenta el concejo de Plasencia y en el que actúa como testigo el 20 de agosto de 1540, declara tener 45 años y haber estado muchas veces en la obra del puente de Alvalá visitándola. Archivo de la Real Chancillería de Valladolid (en adelante, A.R.Ch.V.), Pleitos Civiles (en adelante, P.C.) La Puerta, c. 299-8, s.f. Sobre Correa,
} 


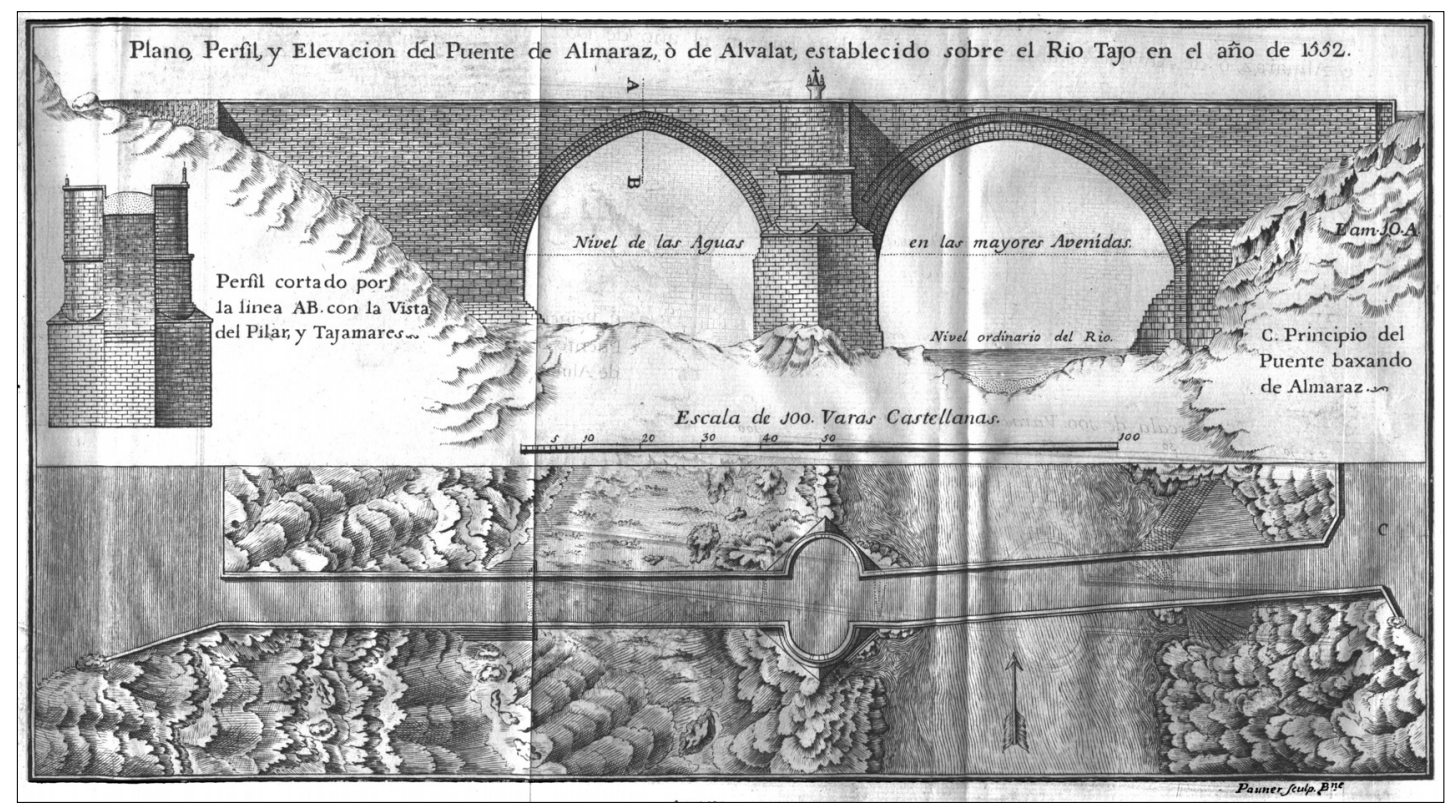

El puente de Almaraz según Miguel Sánchez Taramas, inserto en la obra de John Muller, Tratado de fortificación. Barcelona, 1752 (reproducido del ejemplar de la Biblioteca de la Universidad de Granada BHR/ A-041-264 (2).

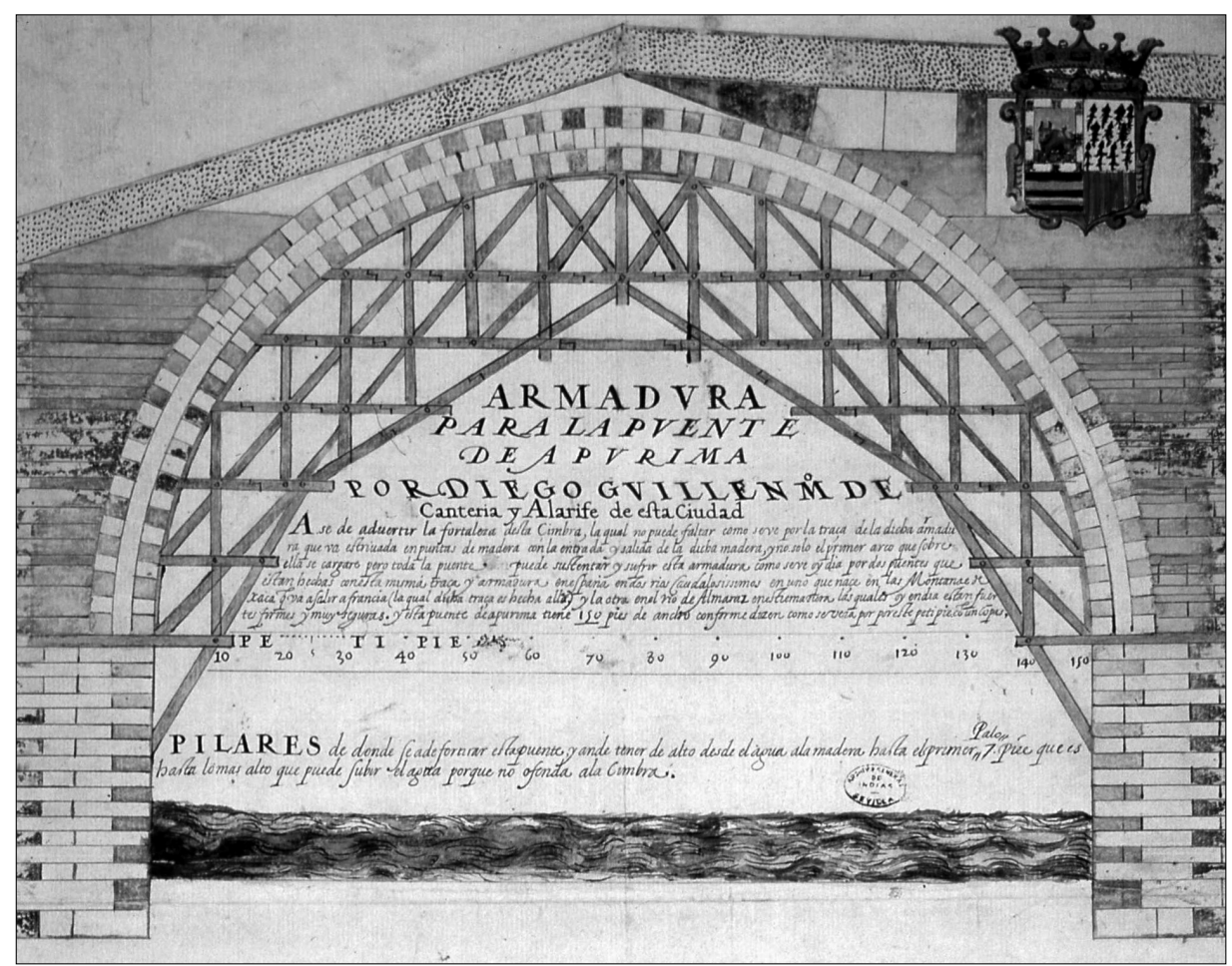

Cimbra del puente de Apurímac (Perú), proyectado c. 1619 por Bernardo Florines, ingeniero, y Diego Guillén, maestro de cantería, utilizando la misma traza y armadura que el puente de Almaraz. Archivo General de Indias, Perú y Chile, 203. 
El problema más importante para Ordieta y Correa residía en el esviaje del arco principal: echando un cordel de una orilla a otra, resultaba que el pilar que estaba hacia la parte de Almaraz "está caydo hazia la parte de abaxo honze pies" respecto al pilar central principal, lo cual comprobaron con escuadra y cordel, resultando un esviaje de tres pies, "que es estar las dovelas del arco principal tres pies la punta que está la parte de avaxo del agua más que la de arriva"; ello incrementaba la dificultad (el esviaje era más trabajoso para cerrar) e iba en detrimento de la belleza del puente, aunque no de su fortaleza, gracias a los estribos extremos, cimentados sobre rocas, y al pilar central, muy grande y fornido ${ }^{22}$. Otra de las sugerencias conjuntas fue de gran trascendencia en la configuración del puente, tal y como hoy lo conocemos: que "se quite [el pilar pequeño] para se hazer un arco solo, de manera que quieren hazer solos dos arcos en toda la puente y quitar el dicho pilar pequeño".

Tras la propuesta de Ordieta y Correa, el 4 de marzo de 1539 el licenciado Mercado, del Consejo Real, toma la determinación de eliminar uno de los ojos del puente porque "sería mejor y más fuerte y menos costoso". Aún así, la decisión queda pendiente de la visita de otro maestro, el que hacía el puente de Medellín sobre el Guadiana, para que -juntamente con Ordieta y Correa- diese su parecer e incluso se le contratatase como maestro, con el mismo salario que recibía en Medellín. Si este maestro estuviera de acuerdo con la reducción del puente a solo dos ojos, entonces se habría de atender a la edificación del "pilar del cavo" (el que estaba hacia la venta) hasta igualarlo con el principal y se iniciaría también el segundo $\operatorname{arco}^{23}$.

El licenciado Mercado toma otras decisiones importantes: manda acabar el pilar grande hasta igualar con el pilar del risco (recordemos que entre ambas había cinco hiladas de diferencia, según la visita del 1 de marzo), "y no se suba más hasta que se haga el arco"24.

Asimismo, decide sacar a subasta separadamente las obras de carpintería y cantería. Es lógico si pensamos que el trabajo de los carpinteros en la construcción de puentes era muy especializado. Por una parte, se sacará a subasta la cimbra del arco principal, estableciéndose como día del remate el 15 de marzo. Posteriormente, se sacaría a subasta la extracción de las piezas de cantería: "que hagan pública luego por pregonero y por çédulas y en las iglesias el sacar de las piedras de dovelas e anillos y pieças principales y syllares". Se determina como día del remate el 20 de marzo. Estas piezas se transportarían en carretas desde la cantera hasta pie de obra, indemnizando a los dueños de los campos si se provocara alguna pérdida en tierras de cereal. Con ello se intentaba evitar algunos pleitos, como el que les enfrentó con don Francisco de Monroy, Conde de Deleitosa y señor de las villas de Belvís y Almaraz ${ }^{25}$.

ver Benavides Checa, J.; Prelados placentinos. Notas para sus biografías y para la historia documental de la Santa Iglesia Catedral y ciudad de Plasencia, Plasencia, 1907, pp. 77 y 124-125. LÓPEZ MARTín, J.M.;"La arquitectura religiosa en Plasencia: las catedrales antigua y nueva”, en VIII Centenario de la Diócesis de Plasencia (1189-1989). Jornadas de Estudios Históricos, Plasencia, 1990, p. 133. Algunas noticias del desaparecido convento de San Francisco en Oropesa (construido después de 1515) en León Tello, P.; Archivo de los Duques de Frías. Tomo III: Condados de Oropesa y Fuensalida, y sus agregados, Madrid, 1973, p. 74.

22 Ordieta y Correa proponen volverlo en cuadrado sin desasentar las piedras ya colocadas, ganando los tres pies del esviaje en las dovelas que se colocarán al cerrar el ático.

23 Parece ser que el maestro de Medellín, de momento, no acudió, sino que finalmente fue el licenciado Alderete, del Consejo Real y presidente de la Mesta, el que fue a Medellín del 22 al 25 de febrero de 1540 a visitar el puente sobre el Guadiana que se hacía cerca de la villa. Más adelante (el 27 de febrero de 1542) se le volvió a requerir para que visitase el puente y en esta ocasión sí aparece su nombre: Alonso Delgado.

24 Según la declaración de Juan de Lisbona el 2 de marzo de 1540, el pilar grande y el pilar del risco se acabaron de igualar el año 1539; entonces la obra recibió la visita de Martín de la Ordieta y Juan Correa.

25 El conde de Deleitosa impedía la extracción de piedra de las canteras que estaban cerca del puente, por ser término de sus villas, según consta en una provisión real del 29 de marzo de 1539, transcrita por Benavides Checa y procedente del archivo de la Casa del Conde de Oropesa. En una segunda provisión, otorgada en Toledo el 10 de mayo de 1539, el Conde de Deleitosa promete cumplir lo señalado por el rey, con la condición de que la ciudad de Plasencia se obligase a pagar el daño que por sacar la piedra se hiciese a su tierra. BENAvidEs CHECA, op. cit., pp. 207-209. 
Transportadas las piezas a pie de obra, se indica que haya un número suficiente de maestros y canteros para labrar, "en espeçial, lo de los anillos y dovelas", estas últimas "de a seys pies" para el arco principal.

\section{La subasta de los destajos (1539-1540): Diego de Vergara y Martín de la Ordieta ${ }^{26}$}

La ciudad de Plasencia, tal y como había indicado el visitador real, sacó a destajo en 1539 separadamente los trabajos de carpintería y de cantería, desoyendo las opiniones contrarias de Correa y Ordieta, a favor del sistema de jornales ${ }^{27}$. Para la construcción de las cimbras se convocó una subasta con un precio de salida de 3.000 ducados.

Sin embargo, al poco tiempo -aunque en el mismo año de 1539-, el concejo de Plasencia decidió rematar cantería y carpintería conjuntamente por precio de salida de 8.000 ducados. Acudieron a la subasta Diego de Vergara, vecino de Salamanca, asociado con el aparejador Martín de la Ordieta. El 30 de mayo de 1539 presentaron en Plasencia las condiciones para la obra.

Diego de Vergara era un cantero vasco, natural de la villa de Urretxu en Guipúzcoa, donde nació hacia 1499. Pertenecía a una familia de canteros: su padre, Pedro de Echaburu, fallecido en 1549, actuó no sólo en el País Vasco y Navarra, sino también en Salamanca. Ambos hacen su aparición en esta ciudad en 1529: Diego figura entre los canteros que trabajan en la Catedral Nueva; posteriormente, bajo la dirección de Juan de Álava, asume dos destajos sucesivos en la catedral, que le vinculan a la obra entre 1534 y 1542. Sin embargo, ya desde 1538 le vemos actuar en Extremadura, pues trabaja como destajista de la Catedral de Coria, para acabar su carrera en Málaga, donde trabajó en la catedral, primero a las órdenes de Fray Martín de Santiago y finalmente como maestro mayor ${ }^{28}$.

Las condiciones que dieron Vergara y Ordieta afectaban exclusivamente al ojo o arco principal. Este iría apoyado sobre el pilar central y el pilar llamado del risco y requería, en primer lugar, la construcción de la cimbra. Las cimbras se apoyaban en canes dejados en las pilas a la altura del arranque de los arcos o mechinales huecos, como todavía se puede observar en el arco sur del puente de Almaraz ${ }^{29}$.

En las condiciones que estamos analizando se indica también que habrán de corregir el esviaje del arco principal, igualando los paramentos laterales o tímpanos (rincones y enjutas en el texto) hasta alcanzar la altura del arco principal. Esta era una operación delicada que tenía lugar tras

\footnotetext{
${ }^{26}$ Salvo que se indique, la información de este apartado procede de A.R.Ch.V., P.C. La Puerta, c. 299-8, s.f. Se trata de un pleito entre el carpintero Alonso Macías, vecino de Salamanca, y la ciudad de Plasencia.

${ }^{27}$ El 2 de marzo de 1539, tras discutir entre sí y con muchos expertos, Juan Correa y Martín de la Ordieta se decantaban por los jornales frente a los destajos, asumidos por profesionales especializados, bajo vigilancia de maestros, pues se obtendrían mejores resultados en la ejecución de las cimbras, mayor fortaleza, se evitarían peligros a los trabajadores y finalmente resultaría más barato, pues la experiencia enseña que el objetivo de los destajos es procurar beneficios. A.G.S., Consejo Real 547, s.f.

28 Sobre Vergara, ver especialmente PÉREZ DEL CAMPO, L.; "Versatilidad y eclecticismo. Diego de Vergara (h. 14991583) y la arquitectura malagueña del siglo XVI", Boletín de Arte, Málaga, no 7, 1986, pp. 82-83. También BARRIO LOZA, J.A. y Moya VALGañón, J.G.; "Los canteros vizcaínos (1500-1800). Diccionario biográfico". Kobie, Bilbao, n 11, 1981, pp. 206-207. REDONDO CANTERA, M.J.; "Los arquitectos y canteros del entorno de Rodrigo Gil de Hontañón en Castilla y León: la herencia paterna”, en Rodrigo Gil de Hontañón. V Centenario, Santander, 2003, p. 71. CASTRo SANTAMARÍA, op. cit., pp. 262-268 y 403-404. La vinculación Fray Martín de Santiago y Vergara puede ser anterior, ya que en enero de 1536 Fray Martín figura recibiendo dinero del destajo de la Catedral de Salamanca en nombre de Vergara. Archivo de la Catedral de Salamanca, Libro de Fábrica, legajo 2, cajón 44, $\mathrm{n}^{\circ}$ 1, fol. 16 r . Asimismo, le vemos actuar como testigo en la carta de fianza para la obra del puente de Albalá que otorgó Vergara el 26 de enero de 1540.

${ }^{29}$ Más detalles de la construcción de cimbras en GonZÁLEZ TASCón, op. cit., p. 122.
} 
el descimbrado, momento en que el empuje se transfiere a los pilares. Las enjutas son una de las partes más importantes de un puente, pues tienden a desriñonarse, lo que se neutraliza con grandes tímpanos y fuertes rellenos en el intradós. Al tiempo, han de elevar la altura del pilar del risco "çinco o seys pies o más más alto quel pilar grande, por causa que ansy conviene al byen de la obra" 30 . Una vez cerrado el arco principal, se obligan a losarlo (para evitar el deterioro producido por el agua y los orines de las bestias si penetraban en el interior) y a ponerle "açitaras" o antepechos de piedra, que sirven de protección a los transeúntes.

El puente se constituiría también de alguna manera en soporte de mensajes. Por una parte, se determina que en el arco principal llevará "los escudos de armas del emperador y de la çibdad", puesto que monarquía y municipio fueron los responsables de la construcción; estos escudos finalmente se colocaron en el pilar central, aguas abajo. Por otra parte, la simbología religiosa tampoco era ajena a los puentes y, así, en muchos de ellos se colocan capillas o, como en el caso de Almaraz, "un humilladero muy bien fecho con la ymagen de Nuestra Señora como está en la puente nueva desta çibdad [Plasencia] e mejor sy mejor quisieren... a do fuere señalado por los dichos señores" 31 . Aunque no existe en la actualidad, en el grabado de Sánchez Taramas se puede apreciar su presencia.

El concejo de Plasencia se obligaba a entregarles el material (madera, piedra, cal, clavazón) puesto en "la casa de la obra". Los maestros contratistas, por su parte, eran los responsables de contratar la mano de obra. Ellos serán los encargados de labrar "ansy dovelas como syllares, arquillos, esquinas e losadura y antepechos y escudos de armas". Todo habría de quedar acabado en perfección, a satisfacción de los regidores de Plasencia y a vista de oficiales expertos. A esta obligación añaden la de enmendar cualquier falta o reconstruir lo que pudiera caerse, a su costa o a la de sus fiadores.

En las condiciones no queda cerrado el tipo de contrato, que podría ser destajo o maestría. En el primer caso cobrarían un total de 8.000 ducados y parece claro que es la opción preferencial por parte de los maestros, fundamentalmente por los mayores beneficios económicos que se obtenían. En el caso de que el concejo de Plasencia prefiriese la maestría, solicitan cobrar un total de 40.000 maravedís al año para ambos maestros (Vergara y Ordieta), más 4 reales cada día trabajado, incluyendo en ello los días de desplazamiento desde sus casas. En ningún caso se indican plazos de ejecución ${ }^{32}$.

Una vez elaboradas las condiciones por Vergara y Ordieta, la dinámica era la habitual en este tipo de obras: la obra se pregona y se hacen pujas a la baja, rematándose en aquel que lo diera más barato, manteniendo o mejorando las condiciones. Para favorecer las subastas a la baja, se recurrió a los "prometidos", un sistema que debió ser habitual en la época. La persona o institución que encarga la obra prometía pagar un dinero al maestro que hiciera una baja, aunque no se le adjudicara la obra de manera definitiva. Este dinero o "prometido" se cobraría sólo en caso de que se produjeran nuevas bajas con posterioridad ${ }^{33}$. Esto activaba el interés por las pujas, pues algunos sólo buscaban ganar

\footnotetext{
30 Esta es una condición un tanto sorprendente, que daría un perfil inclinado al puente; quizá por ello no se hable de la colocación de caños laterales para facilitar el desagüe de las lluvias, desagües que serían imprescindibles en puentes de rasante horizontal. GoNZÁLEZ TASCÓN, op. cit., p. 124.

${ }^{31} \mathrm{Sin}$ descartar la función religiosa del humilladero, la presencia de este elemento constructivo puede obedecer a un reforzamiento de la tensión vertical, como sucedía también con la inclusión de torres o incluso casas sobre los puentes. Aramburu-Zabala, op. cit., p. 18.

32 En la visita de 1540, el licenciado Alderete determina un plazo de ejecución de tres años. A.G.S., Consejo Real 547, s.f.

33 Así queda explicitado, por ejemplo, el 2 de junio de 1539, cuando se presenta una baja por parte de los carpinteros salmantinos Macías, Sánchez, Ceballos y Sedeño, quienes bajaron la obra del puente a 6.000 ducados por 70 de prometido, que sólo cobrarían en el caso de que se produjeran nuevas bajas con posterioridad. Sin embargo, en el caso del muelle de Santander, parece que el prometido sólo se adjudicaba al que lograba el remate, con la pretensión de evitar la "confederación" de los maestros para no hacer pujas a la baja. Aramburu-Zabala, M.A. y Alonso Ruiz, B.; Santander: un puerto para el Renacimiento, Santander, 1994, pp. 157-158. Sobre la dinámica de las subastas, ver ARAMBURUZabala M.A., op. cit., pp. 28-29 y GonZÁleZ TASCón, op. cit., pp. 65-66.
} 
estos "prometidos". No descartamos que en el caso del puente de Albalá hubiera una cierta connivencia entre los postores para obtener el beneficio de los prometidos, y eso que las autoridades solían cerciorarse de que no existieran acuerdos previos secretos que distorsionaran la subasta.

Cuando Alonso Macías -actuando en nombre de Miguel Sánchez, Fernando de Ceballos y Francisco Sedeño, todos ellos carpinteros y vecinos de Salamanca ${ }^{34}$ - acudió a la subasta, le comunicaron los cambios que el consistorio había introducido, al rematar cantería y carpintería conjuntamente por precio de 8.000 ducados. Alonso Macías reclamó que le pagasen el camino, lo cual cumplió el ayuntamiento de Plasencia, además de enviar con él a una persona que le enseñase el puente, pues manifestó su interés en tomar las obras de cantería y carpintería.

El 2 de junio de 1539 se convocó la subasta y por entonces cesarían las obras, en espera de la resolución de la misma ${ }^{35}$. Como solía ser habitual, la almoneda pública tenía lugar en espacios revestidos de cierta solemnidad, en este caso en las Casas de Consistorio de Plasencia, en presencia de diversas autoridades municipales, bien el corregidor o alguno o varios de los regidores, el juez de residencia y el escribano y notario público.

El pregonero de la ciudad pregonaba la postura y condiciones de la obra "a altas boces" en la plaza pública. A la subasta acudieron los carpinteros salmantinos asociados y el aparejador Martín de la Ordieta, actuando también en nombre de Diego de Vergara. Tras varias pujas a la baja por parte de ambos postores, finalmente los carpinteros salmantinos rebajan la obra a 6.000 ducados por 70 de prometido, cantidad que sería la finalmente aceptada ${ }^{36}$. Quedaba únicamente el trámite de las fianzas, para lo cual disponían hasta finales del mes de julio.

Sin embargo, al pregonarse el 3 de junio en la plaza pública de Plasencia esta baja y posturas, se produjeron nuevas rebajas: Martín de la Ordieta reduce el prometido a 30 ducados manteniendo las mismas condiciones y, tres días después, el mismo Ordieta rebaja la obra 500 ducados más (es decir, la deja en 5.500) y 50 de prometido.

La importancia de la obra justifica que la nueva baja se mande pregonar por importantes ciudades más allá del entorno: Salamanca, Toledo, Medina del Campo, Talavera de la Reina, Valladolid, Segovia y Ávila ${ }^{37}$. En todas ellas se manda poner edictos para favorecer nuevas bajas por parte de "los maestros artistas, ofiçiales de cantería y carpintería destos reygnos y señoríos", a los que se convoca para el 31 de julio, día del remate.

Pero antes de esta fecha se presentan varias bajas, que van reduciendo progresivamente tanto el precio de la obra como el prometido. Participan Francisco Fernández o Hernández, carpintero y vecino de Plasencia ${ }^{38}$; Diego de Vergara ${ }^{39}$; Juan Correa, maestro de cantería y vecino de

${ }^{34}$ El poder fue otorgado en Salamanca el 27 de julio de 1539, ante el notario Julián Palomeque. Sólo Miguel Sánchez firmó, pues Ceballos (o Zaballos) y Sedeño (o Sedano) no sabían escribir.

35 Así lo afirma el 1 de marzo de 1540 un testigo, Andrés de Trejo, quien conoce a uno de los maestros que trabajaban en la obra, Juan de la Rinça (en otras ocasiones citado como Juan de Larracina, de la Rinza, Rancia o Rainza), que está inactivo. A.G.S., Consejo Real 547, s.f.

36 Primeramente Macías bajó la obra a 7.000 ducados por 50 de prometido. Ordieta la rebajó también en 1.000 ducados pero reduciendo el prometido a 40. Miguel Sánchez lo rebaja a 30, a lo que reacciona inmediatamente Ordieta, poniendo el prometido en 20 ducados, para posteriormente renunciar a todo prometido. Finalmente, los carpinteros asociados que se quedaron con la obra ofrecieron a la ciudad la posibilidad de trabajar a jornal y maestría. El concejo de Plasencia pretendió excusarse de pagar el prometido de 70 ducados, alegando que Macías no presentó fianzas, aunque finalmente el concejo es condenado por sentencia definitiva a pagarle el prometido.

${ }^{37}$ Los pregones tienen lugar entre los días 11 y 19 de junio en las plazas públicas más importantes y los edictos quedaban fijados en los ayuntamientos o catedrales.

${ }^{38}$ El 1 de julio rebaja la obra en 500 ducados (es decir, la haría por 5.000 ducados), más 50 de prometido. El 29 de julio vuelve a rebajarla, dejándola en 4.200 ducados por 30 de prometido.

39 El 1 de julio Diego de Vergara, actuando en su nombre y en el de Martín de la Ordieta, la deja en 5.000 ducados y 12 de prometido "para su camino". 
Plasencia ${ }^{40}$; Pedro de Ybarra, Juan Negrete y Miguel de Aguirre, maestros de cantería y vecinos de Salamanca ${ }^{41}$. Por último, puja Bartolomé Rodríguez, maestro de carpintería y vecino de Salamanca, que hizo un baja que podemos considerar temeraria, pues reduce el precio a 3.200 ducados por 120 de prometido. El problema de Rodríguez es que no encuentra fiadores ${ }^{42}$ y ha de sacarse la obra de nuevo a remate, con los consiguientes retrasos. El 5 de diciembre de 1539 concurre de nuevo Martín de la Ordieta y pone la obra en 4.600 ducados.

Se pregona la obra con esta nueva postura varios días en la ciudad de Plasencia, declarando como fecha del remate la víspera de Pascua de Navidad, que se alarga hasta el día de Reyes del año siguiente, a petición de Pedro de la Puente, vecino de Salamanca ${ }^{43}$.

Por fin, el 6 de enero de 1540 comparece Diego de Vergara, que deja la obra en 4.000 ducados, exactamente la mitad de lo que habían establecido en las condiciones de los destajos de 1539. Como debía ser habitual, a la puesta de sol, se hizo el último pregón y “desque no ovo quien baxase, se remató, diziendo a la una, a las doss, a las tres, pues que no ay quien de más" y se adjudicó a Vergara. El 26 de enero otorga fianzas ${ }^{44}$.

Desde 1538 y hasta marzo de 1540 Juan de Tobar, veedor y mayordomo de la obra, se había ocupado de proveer de material: hizo sacar más de 6.500 varas de sillares, 2.300 varas de dovelas, 60 piezas grandes de 6 pies; hizo traer más de 1.900 carretadas de piedra desde las canteras y 4.800 fanegas de cal. En ello trabajaron los canteros Pedro de Ávila, Alonso de Puenles, Juan Bueno y Juan de Larracina ${ }^{45}$.

40 El 2 de julio rebaja la obra en 5.000 ducados, pero sin prometido ninguno ni para él ni para ningún otro implicado en las posturas. Figura como maestro de cantería y vecino de Plasencia, pues era el aparejador de la catedral.

41 Comparecen en Plasencia el 25 de julio y rebajan la obra a 4.500 ducados por 60 de prometido. Según declara Juan de Lisbona, se alojaron en su casa. A.G.S., Consejo Real 547, s.f. Estos tres maestros canteros acabarán poniendo una demanda al concejo de Plasencia porque todavía el 26 de mayo de 1542 se les debían los 60 ducados de prometido. La sentencia definitiva del 10 de febrero de 1543 condena a la ciudad de Plasencia. A.R.Ch.V., P.C. La Puerta (o.), c. 299-3 y Reales Ejecutorias c. 548-1 y c. 578-1. Curiosamente, desde el 15 de mayo de 1537 estos tres maestros y Diego de Vergara eran compañeros en los destajos de la Catedral de Salamanca, aunque aquí fueran competidores. CASTRO SANTAMARÍA, op. cit., pp. 265-268.

42 Presenta su rebaja el 30 de julio. Respecto a las fianzas, argumenta que sus compañeros Francisco Rodríguez, carpintero, Juan de Sarasola y Machín de Sarasola se habían comprometido verbalmente con él y después eludieron el compromiso. Como consecuencia de este incumplimiento el 13 de diciembre Francisco Rodríguez y Bartolomé Rodríguez reciben una carta de requerimiento para que asuman la quiebra de 1.400 ducados, que cobrarán de sus bienes.

43 Baja la obra a 4.200 ducados y alarga el remate al día de Reyes para dar fianzas, obligándose a pagar los 400 ducados que baja en caso de no conseguirlas. Hasta la fecha, Martín de la Ordieta no había presentado fianzas por su baja. Como finalmente Pedro de la Puente no obtuvo el remate, la ciudad le paga 8 ducados por su trabajo y el desplazamiento. No es la primera vez que aparece su nombre: en 1534 informa para la Orden de Alcántara sobre la fortaleza de Eljas y en 1535, como natural de Laredo, había sido testigo por parte de Juan Sánchez de Alvarado en el pleito que sostiene éste con el cabildo de Salamanca por los destajos de la obra. Sin embargo, su nombre ha pasado a la historia más bien como aparejador de la catedral de Ciudad Rodrigo, a las órdenes de Rodrigo Gil, desde 1545. A.R.Ch.V., P.C. Fernando Alonso (F), c. 110-4, s.f. NAVAREÑo Mateos, A.; Arquitectura y arquitectos del siglo XVI en Extremadura, Cáceres, 1994, p. 24. Sánchez lomba, op. cit., p. 104. Hernández Vegas, M.; Ciudad Rodrigo. La Catedral y la Ciudad, Ciudad Rodrigo, 1935, tomo II, p. 168.

${ }^{44}$ Esto era lo habitual y así había quedado establecido en la escritura de concierto del 30 de mayo de 1539. Los fiadores eran vecinos de Salamanca: Cosme de Castro, el bachiller Francisco González, el barbero Pedro de Paz, el chapinero Juan Méndez, Juan Sánchez de Miranda, mayordomo de Santa María de las Dueñas, y Pedro Vázquez, sastre. Para averiguar si los fiadores tienen suficiente respaldo económico, se abre un largo proceso de información, que incluye interrogatorio y declaración de testigos.

45 Según Juan de Lisbona, los canteros sacadores procedían de Almaraz, Belvís y Plasencia. El 1 de marzo de 1540 se señala que hacía pocos días que había cesado la provisión de piedra, debido a la esterilidad del tiempo y la flaqueza de los bueyes. Los precios que se pagan a los canteros labrantes son: $20 \mathrm{mrs}$. la vara de sillar, a 1,5 reales la dovela y a 3,5 reales las piezas; la fanega de cal se pagaba a 11 mrs.. A.G.S., Consejo Real 547, s.f. 


\section{Las visitas de 1540, 1541 y 1542}

La visita del presidente del Concejo de la Mesta, licenciado Alderete, el 3 de marzo de 1540, nos permite conocer el estado de la obra en esta fecha. Junto a él se hallan presentes algunos regidores, el obrero (Juan de Tobar) y Ordieta (nombrado como "veedor"). Poco habían avanzado las obras este último año: se había "ygualado el migajón del pilar del risco con el pilar grande de en medio de la puente e se hecharon las dos hiladas que mandó el señor licenciado Mercado de Peñalosa...agora un año"46.

En un mandato, Alderete recogerá las pautas para la obra. En primer lugar, se asentará el destajo del arco y cimbra con Diego de Vergara, conforme a las condiciones con que se remató, por 4.000 ducados. Pero ha de tomar más fianzas de las dadas, que ascenderían a 10.000 ducados ${ }^{47}$. Se establece el plazo de ejecución en 3 años.

En este mandato se atiende a la construcción (parcial) del segundo arco, que se ha de labrar antes, para evitar golpes y movimientos. Se manda al aparejador, maestre Martín, deshacer 8 hiladas del pilar grande, de la parte que responde al "pilar chico" para comenzar "la buelta del arco que se ha de hazer a la otra parte de la puente", asentándose 14 hiladas, "de manera que quede retunbeado". Después se hará el arco principal, del que se encargará Vergara.

Manda cesar la extracción y labra de piedra, al tiempo que se encarga a Juan de Tobar, veedor y mayordomo, elaborar un memorial de los materiales. Respecto a la madera, Vergara debe ver la que hay y encargar la que falte.

Un año después, el 9 de marzo de 1541, Alderete efectúa de nuevo una visita a la obra, "en la qual estavan hechos dos pilares grandes por cada una parte del río de Tajo... y ençima de cada uno de los dos pilares se començava ha hazer la çinbia". Observó "buena diligençia" en la obra. Como lo más importante era cerrar el arco principal, ordenaba al regimiento que cada mes enviase a visitar la obra a "una persona de las que más ynformados estuviesen del hedefiçio". Además, mandó que el corregidor o su lugarteniente visitasen la obra dos veces al año (en octubre y abril) y que cumpliesen lo contenido en un memorial entregado por Vergara (que no conocemos). Por último, como quedaban algunos repartimientos por cobrar, se iba a solicitar prorrogación del repartimiento por tres años más, "porque no çese la obra de la dicha puente".

Como parecían existir problemas, se ordenó -por provisión real del 27 de febrero de 1542- visitar la obra a Alonso Delgado, vecino de Badajoz, "maestro de la obra de la puente de Guadiana que se haze en la villa de Omedelín", quien se presenta el 3 de marzo, encontrándose las cimbras caídas. Según su parecer, las causas residían tanto en la carpintería como en la cantería: por una parte, la cimbra no estaba bien construída, por falta de fundamento, ya que las "rostras" desploman la obra hacia fuera al haber cargado el peso de la obra sobre las cabezas de aquellas; por otra parte, "la cantería está mal elegida y algo torçida la puente". La solución sería colocar cimientos de piedra de cantería (de 24 o 25 pies por una parte y de 8 por otra) que alcancen la altura de los jarjamentos y soporten las cimbras, desde donde se alzarán tres arcos de madera ${ }^{48}$.

\footnotetext{
46 A.G.S., Consejo Real 547, s.f., de donde procede la información de estas últimas visitas. Migajón es hormigón de grava y arena, según GONZÁLEZ TASCÓN, op. cit., p. 433.

47 Así lo declara el 1 de marzo de 1540 Juan de Tobar, veedor y mayordomo de la obra, que se lo oyó decir al aparejador, maestre Martín (de la Ordieta).

48 Alonso Delgado ya había sido reclamado para dar su opinión con anterioridad, en 1539, aunque parece que finalmente no acudió. Hasta ahora, el casi desaparecido puente renacentista de Medellín sobre el Guadiana se atribuía al maestro trujillano Sancho Cabrera, que lo concluyó en 1575. Andrés OrdaX, S.; GonZÁlez ToJEIRo, C.; Mogollón Cano-Cortes, P. y Navareño Mateos, A.: Testimonios artísticos de Medellín (Extremadura), Salamanca, 1985, pp. 8187. Según la definición de Covarrubias, riostra son los maderos con que aseguran el pie derecho puesto a nivel, en tanto que le cargan con la suela. GonZÁlez TASCón, op. cit., p. 441.
} 
Marcos Díez, procurador del Concejo de la Mesta, en una carta de dirigida a los regidores de Plasencia, hace recaer la responsabilidad de los desperfectos en la ciudad de Plasencia, por su negligencia al dejar de cobrar más de 200.000 maravedíes del reparto, y en el maestro Diego de Vergara, que perdió en madera, alba y otros pertrechos la cantidad equivalente a 500 ducados, de los que la ciudad debía hacerse cargo. Por último, solicita que Alonso Delgado, maestro de cantería, esté disponible para dar su parecer sobre la obra del puente ${ }^{49}$. La justicia y regimiento de Plasencia es condenada a continuar la obra, dotándola de materiales y dinero.

\section{Fin de las obras}

Desafortunadamente, aquí se acaban las noticias relativas a la construcción. En 1542 la obra estaba lejos de concluirse. Según Ceán en las adiciones a Llaguno, no fue Diego de Vergara quien acabó la obra, sino Pedro de Uría. Obtiene la información de una inscripción que figuraba en el propio puente, pero que no hemos logrado localizar. En ella se decía: "Esta puente hizo la ciudad de Plasencia año de 1552, reinando en España la magestad cesárea de Carlos V Emperador. Fue maestro Pedro de Uría". Efectivamente, en 1551 Diego de Vergara se refiere al puente de Albalá, que dejó comenzado, y cuya finalización confía a otro vizcaíno que también residía en Málaga: Pedro Uría, su aparejador, quien tampoco ultimaría la obra, sino que lo haría Ortuño de Azurriola, vasco y asentado en Málaga, a quien Vergara encarga cobrar alguna cantidad ${ }^{50}$.

\section{Financiación y gestión de las obras}

A través de la documentación parece deducirse que el trabajo en el puente durante el periodo estudiado (1533-1542) fue discontínuo, no sólo por el ritmo natural de las obras, marcado por las estaciones (en este caso el verano era la época inactiva), sino por los problemas de índole económica, fundamentalmente ${ }^{51}$.

La obra se financió por el sistema de "repartimiento" entre los pueblos que recibían beneficio por su construcción. Era el sistema más habitual, como ha estudiado Aramburu-Zabala. En este caso se recaudó por orden del Rey entre cuarenta y nueve pueblos de las tierras de Plasencia, que contribuían de manera proporcional al número de habitantes, hasta un total de 750.000 maravedíes en 1534, millón y medio antes de 1536, 400.000 en 1536 y otros tantos en 1537. A partir de esta fecha se añadieron al reparto las ciudades de Trujillo, Cáceres "e los otros pueblos que reciben benefiçios". En

49 Por supuesto, la ciudad rebate sus argumentos: la elección de Vergara tuvo la aprobación de Alderete, del Consejo Real; en el caso de que hubiera algún daño causado por él, tiene dadas fianzas. Sin embargo, finalmente la ciudad de Plasencia fue condenada por el Presidente de la Mesta a requerir a Vergara y sus fiadores el dinero perdido, obligándoles a cumplir las escrituras. Respecto a la presencia de Alonso Delgado, la ciudad de Plasencia exige que lo pague el Concejo de la Mesta, pues vino por su petición, y así lo hizo: recibió 6 reales diarios por cada uno de los ocho días que estuvo. La ciudad, por su parte mandó llamar a Francisco Fernández y se ocupó de pagarle. Era un carpintero residente en Plasencia, que había pujado por los destajos de 1539.

50 Llordén, op. cit., pp. 12-20. La inscripción en LlaGUNO y AmiROLA, op. cit., tomo II, p. 57.

${ }^{51} \mathrm{La}$ actividad cesaba en la época estival (desde San Juan hasta septiembre), sin duda por las altas temperaturas. Así lo indica un testigo, Andrés de Trejo, que declara en 1540. El 7 de febrero del 1538 se alude a las habituales interrupciones de la obra. Una de ellas fue desde finales de 1534 y durante año y medio. A.G.S., Consejo Real 547, s.f. Salvo que se indique, el resto de la información de este apartado procede de la documentación de este pleito y de las informaciones que recoge QuINTANILLA, art. cit., pp. 242 y 244-250. 


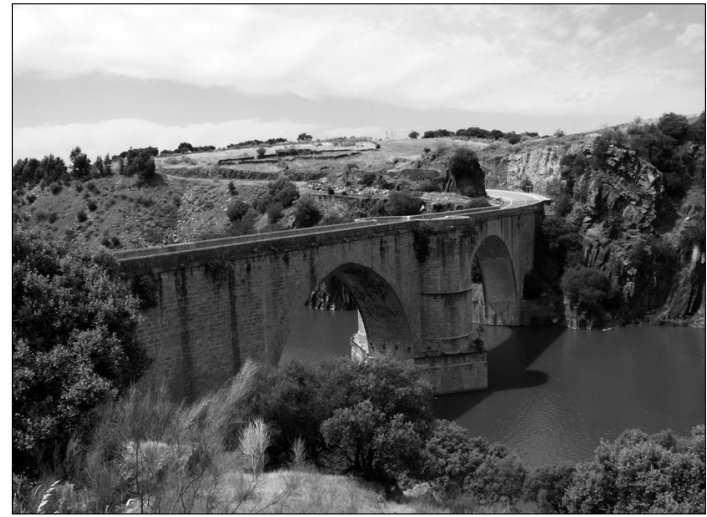

El puente de Almaraz, aguas abajo.

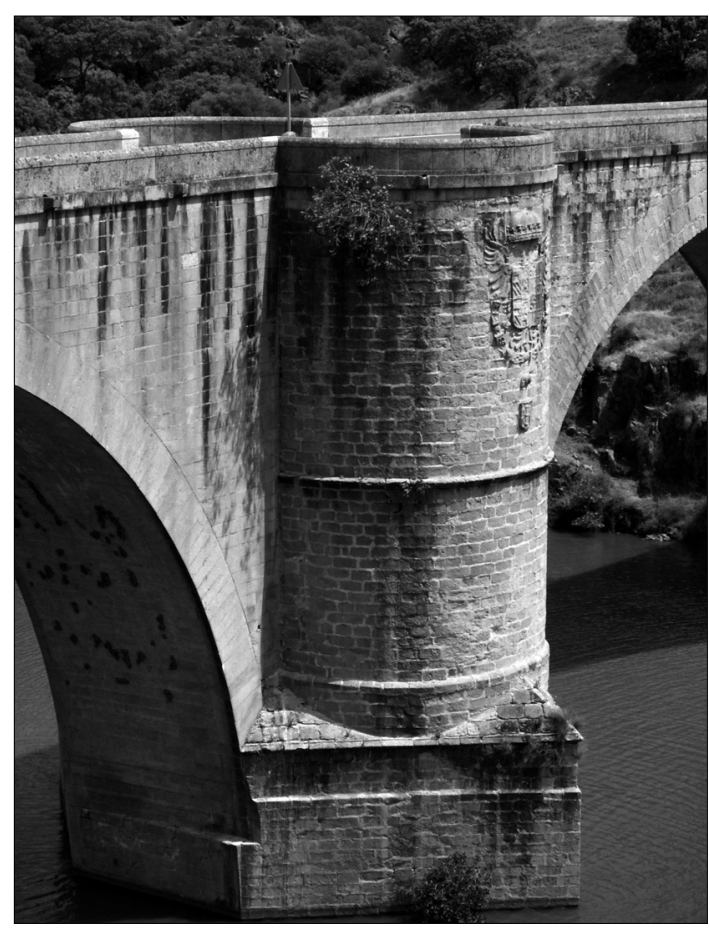

Pilar central, con el escudo imperial y el de la ciudad de Plasencia.

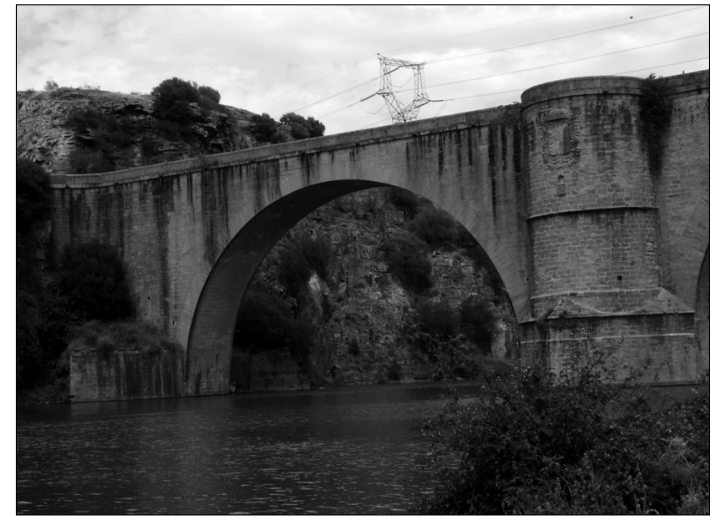

Arco norte (hacia Almaraz) aguas arriba.

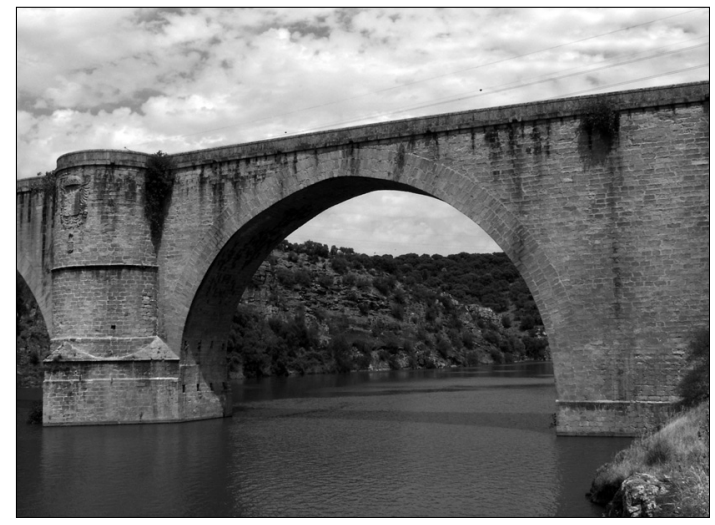

Arco sur, aguas arriba.

1538 se repartieron 450.000 maravedís y otros tantos en 1539; el último dato que poseemos al respecto es de 1542, en que se iban a repartir 200.000 maravedíes $^{52}$.

52 En 1536 se dio licencia para el reparto de 8.000 (o 7.950, se dice en otra ocasión) ducados, de los cuales sólo se habían repartido 4.017. Quedaban por repartir, por tanto, otros 4.000 ducados, pero se indica que no se supere la cantidad de 2.000 al año. Se autoriza a repartir hasta finales de julio de 15362.000 ducados. La relación de los 49 pueblos incluidos 
El esfuerzo económico al que se sometió a los habitantes de la zona provocó incluso la interrupción de la obra desde mediados de 1534, "a causa que los maravidís que se avían repartido heran gastados y que no avían repartido más por la fatiga que los avía de pagar e porque hera la obra tan costosa que no se acabaría con mucho más de aquello". Los más perjudicados por estos repartos eran "los pobres, biudas e que tienen poco", por lo que en la visita de 1536 se decide que paguen más "los ricos e los que gozan más con sus ganados de los... encinares".

A estos ingresos se añadían otras fuentes de financiación, tales como los portazgos, el paso por las barcas de Albalá y las hierbas, paso y cañada del Campo de Arañuelo ${ }^{53}$. Al menos en una ocasión se cuenta con una contribución de 70.000 maravedís aportados por la Mesta.

Los cargos relacionados con la gestión económica son varios (receptor y cobrador, mayordomo, veedor y obrero), pero sus competencias no aparecen claramente deslindadas. El receptor y cobrador era el encargado de la recaudación de los repartimientos, pero la gestión de los mismos se repartía entre varios. Uno de ellos era el mayordomo de la obra, que llevaba los libros de cuentas, aunque a veces mayordomo y receptor son una misma persona. Otro de los cargos era el de veedor y obrero, un puesto a veces ocupado por canteros, aunque no siempre era así, ya que era un cargo vendible; en Almaraz era el encargado de librar las cartas de pago, pero además recibía dinero para los gastos "de por menudo". En 1538 se le encomienda enviar la nómina de oficiales y peones al regimiento de Plasencia, para que esta institución vigile la diligencia que se lleva en la obra. En 1539-1540 mayordomo, veedor y obrero son una misma persona y en este periodo la ciudad de Plasencia le envió " $a$ esta obra a resydir en ella e a hazer sacar piedra e traella e labralla"; además se le manda hacer inventario de los materiales y anotar en un "libro oradado por pliegos" todos los libramientos. A veces, incluso el barquero se hace cargo también de algunos gastos "de por menudo", que en 1540 consistían en ser "pagador de los obreros e carreteros e peones e canteros e otros travajadores... e de otras cosas e materiales" 54 .

A pesar de la fragmentación de tareas -o quizá precisamente por ello-, la gestión no debía funcionar bien, pues el 3 de febrero de 1536 una provisión real señala que "en el edificio de la puente que se haze sobre el río de Tajo, que es tan importante, no se pone el recaudo que es e razón ni los dineros que para ello ay se gasten segund e como deven". La corrupción, tan habitual en las obras públicas en las que se manejaba tanta cantidad de dinero, hizo su aparición en los destajos de Almaraz, "por quanto... a parecido que algunos e mayormente con los destajos han ganado

desde los primeros repartos en QuinTANILLA, art. cit., pp. 244-245. Los pueblos que se añadieron en 1537 fueron Oropesa, Colmenar de Arenas, Garrovillas, Arroyo del Puerco, Fuente del Maestre, Santolalla, Mérida, Arenas y Brozas. En 1537 se recaudan de ellos 186.750 maravedíes. En 1539 se añade Mombeltrán; se recaudan en total 1.262.451,5. A través de las provisiones reales del 6 de febrero de 1537, 3 de febrero de 1539, 13 de febrero de 1540 y 20 de enero de 1541 sabemos que el corregidor y regidores de Plasencia intentaron eximirse del repartimiento. Esto es lo que justifica el control de las cuentas y las obras por parte del Concejo de la Mesta. Sobre el sistema de repartimientos, ver Aramburu-Zabala, op. cit., p. 28 y GonZÁleZ TASCón, op. cit., pp. 56-58.

53 Esto último ascendía a un total de 161.400 maravedíes en 1536 y 100.000 en 1538. En 1536, ante la escasez de recursos económicos, se sugiere arrendar y vender baldíos del municipio.

54 El 16-7-1534 era receptor y cobrador Juan de Hinojosa. El 23-3-1534 ocupaba el cargo de mayordomo y receptor Pedro de Carvajal; entre el 12 de mayo de 1536 y el 3 de marzo de 1542 García Jiménez de Aguilar. En otro lugar el mismo García Jiménez de Aguilar aparece como receptor y cobrador, con un salario de 6 ducados, más tres reales diarios cada día que se ocupare. En 1536 figura como veedor y obrero Marcos Ruiz; recibe 12 ducados de salario. En otro lugar consta cobrando 40 reales de salario al mes. En 1539 y 1540 figura Juan de Tobar como "mayordomo y veedor" (cuando ostentaba el cargo de mayordomo García Jiménez) y en otra ocasión como "obrero". Juan de Lisbona, barquero, cobra 4 ducados al año. El 4 de marzo de 1540 es despedido acusado de cohecho a los carreteros que llevaban la piedra. Sobre el cargo de veedor y obrero, ver ARAmbURU-ZaBALA, op. cit., p. 29. 
largamente en la dicha obra"55. Esta afirmación resulta evidente cuando los documentos nos revelan que el 6 de marzo de 1536 ya se llevaban gastados 7.950 ducados, pero apenas estaban levantados los pilares del puente. En 1538 Martín de la Ordieta seguía pensando que "se ha gastado en el dicho edificio mucha cantidad de maravidís e materiales por mandado del corregidor que no ha seydo bien gastado" y calculaba para acabar el puente la cifra de 30.000 ducados.

Una de las soluciones con las que se pretendió mejorar la gestión tras la visita de 1536 fue la creación de la figura del "dueño", cuya función sería cuidar de la obra como si fuese propia, eliminando otros cargos que multiplicaban los salarios. En 1538, además, se implica en la vigilancia al propio corregidor y regidores de Plasencia, que debían examinar las cuentas, visitar la obra dos veces al año y llevar un control de la nómina de oficiales y peones. En 1539 se añade a esta labor de vigilancia el "procurador de la tierra".

\section{Conclusiones}

El puente de Almaraz no tuvo un planteamiento general inicial. Las decisiones se iban tomando a medida que avanzaba la obra: así, comenzó y continuó teniendo un esgonce o quiebro, determinado por las primeras obras que se iniciarían a finales del siglo $\mathrm{XV}$; se utilizó sillería de granito con relleno de pizarra, cal y arena, aunque en 1537 se dudaba si continuarla así u optar por la mampostería con las esquinas de sillería. Pasó de tener cuatro pilares (que determinarían la existencia de tres ojos) a eliminar uno de ellos, quedando reducidos los ojos a dos, como ya defendían Ordieta y Correa en 1539. De igual manera, parece que la decisión de doblar el dovelaje se tomaría alrededor de 1537, pues así lo apunta ya Pedro de Ávila. También entonces se optaría por concluir en primer lugar el arco principal.

Otro asunto que se debatió en varios momentos fue el tipo de contrato de obra, dudando entre jornales o destajos. Alrededor de 1530, cuando se decidió el inicio de las obras, se contó con un maestro, Juan de Álava, y un aparejador. A partir de 1533 no se vuelve a nombrar maestro y sí aparejador, que seguía siendo Martín de la Ordieta, a pesar de que se habla de varios destajos (el del propio Ordieta y el de Pedro de Ávila). A partir de 1537 se opta por los destajos para levantar el arco principal: al ser otorgados mediante subasta los precios se reducían considerablemente, pero se producían problemas consecuencia de la falta de fiadores por parte de los adjudicatarios, con los consiguientes retrasos en la obra y pérdidas económicas, al tener que volver a iniciarse el proceso de pregones. También se produjeron pleitos por la costumbre de los prometidos. Los propios artífices son conscientes de la corrupción que suelen acarrear los destajos, como expresa Ordieta en 1539 cuando declara que "los que toman a destajo syenpre procuran de ganar lo más que pueden".

La importancia de la obra justifica la publicación de los destajos por medio de edictos en un marco geográfico amplio: Salamanca, Medina del Campo, Valladolid, Ávila, Segovia, Toledo y Talavera de la Reina, si bien finalmente concurrieron canteros y carpinteros placentinos (Francisco Hernández, Juan Correa) y otros del foco salmantino (Pedro de Ybarra, Juan Negrete, Miguel de Aguirre, Bartolomé Rodríguez, Pedro de la Puente), uno de los cuales, Diego de Vergara, se hizo finalmente con la obra.

Como toda obra pública de esta magnitud, la inversión económica fue considerable. Aunque la iniciativa fue del poderoso Concejo de la Mesta, se financió por el sistema de repartimientos,

\footnotetext{
55 En el fraude incluso estaban implicados los corregidores, por haber pasado partidas indebidamente. Sobre el tema, ver Aramburu-Zabala Higuera, M.A.; Fraude y corrupción en la arquitectura del Siglo de Oro, Santander, 2001, especialmente pp. $40-46$.
} 
lo cual hizo recaer el peso económico en la ciudad de Plasencia y los municipios del entorno. Se llegaron a barajar cifras de 12 o 15.000 ducados sólo para el arco principal con sus pilares, o 30.000 ducados para la totalidad de la obra. Constan las quejas por las exigencias económicas, particularmente por parte de los más desfavorecidos.

No todo el dinero se invirtió en la obra: la corrupción hizo su aparición desde los inicios y en todos los niveles: desde los pequeños hurtos de los trabajadores de la obra, pasando por el intento de ganar "prometidos" en las pujas por parte de los canteros (seguramente en connivencia), continuando por los gestores, hasta los corregidores. El sistema de destajos, desde luego, no favorecía la calidad (sí la rapidez, aunque en este caso tampoco se cumplieron los plazos) y la multiplicación de los gestores incrementaba los gastos y favorecía los desvíos. En fin, no se libra ni el barquero, que es acusado de cohecho. El peligro de corrupción es lo que motiva el cercano seguimiento que hace el Consejo Real, que manda anualmente sus visitadores del Concejo de la Mesta, que requieren también la presencia experta de otros maestros constructores de puentes de la zona (Cristóbal Méndez, maestro del puente de Badajoz, Alonso Delgado del de Medellín).

Conocemos el proceso constructivo bastante bien desde 1533 hasta 1542 , periodo en que ni siquiera se terminó de cerrar el arco principal. Por tanto, el gran impulso de las obras tendría lugar en la década siguiente, pero desafortunadamente nuestras fuentes de información cesan.

Recibido: 14-XI-2005

Aceptado: 17-III-2006 